\title{
THE ROLE OF THE INTESTINE IN CALCIUM HOMEOSTASIS IN THE LAYING HEN ( ${ }^{1}$ )
}

\author{
S. HURWITZ \\ Division of Poultry Science, \\ The Volcani Institute of Agricultural Research, Rehovot (Israel)
}

The metabolic pathways of calcium were diagramatically described by BRoNNER and AUBERT (I965) for the rat. In this scheme (fig. I), the various kinetic parameters as well as the various pools are defined mathematically but may be assigned physiological entities. The pool $\left(\mathrm{F}_{1}\right)$ includes blood and soft tissue calcium and some bone calcium. It exchanges, with no net change in mass with compartment $\mathrm{E}_{2}$ which is mostly located in bone. The other symbols represent vectorial movements of calcium in and out of the pool. Calcium moves into the pool by intestinal absorption $\left(\mathrm{V}_{a}\right)$ and bone resorption $\left(\mathrm{V}_{\theta^{*}}\right)$, and out of the pool by bone accretion $\left(\mathrm{V}_{o+}\right)$, urinary excretion $\left(\mathrm{V}_{u}\right)$ and endogenous excretion $\left(\mathrm{V}_{/}\right)$. In laying hens, the system is further complicated by exits into the yolk, and most importantly into the egg shell.

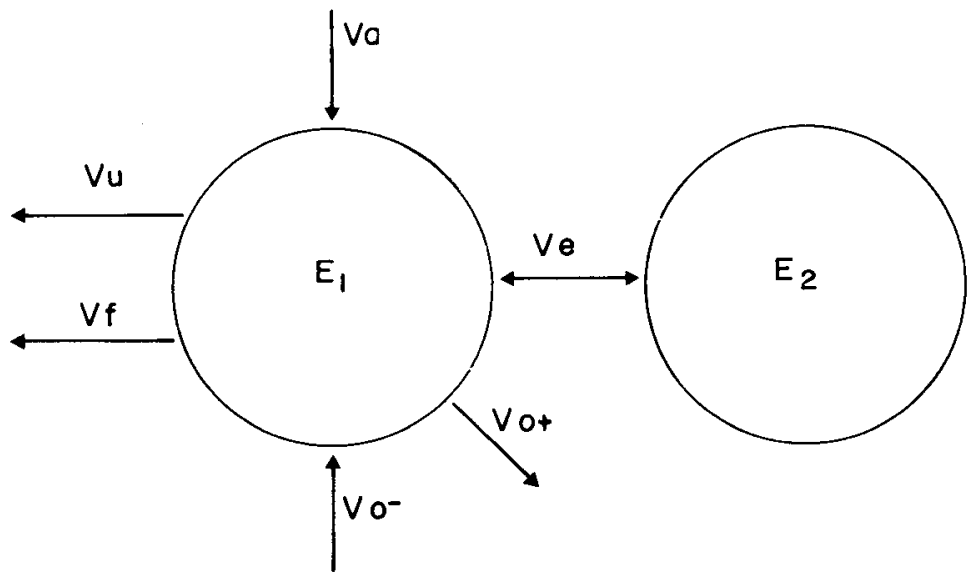

FIG. I. - A model of calcium metabolism in the rat

$\mathrm{E}_{1}=$ compartment containing the more rapidly exchangeable calcium; $\mathrm{E}_{2}=$ compartment containing the more slowly exchangeable calcium. The symbol $\mathrm{V}$ denotes rate as following : $V_{e}=$ exchange between $\mathrm{E}_{1}$ and $\mathrm{E}_{2} ; \mathrm{V}_{a}=$ absorption from the intestine; $\mathrm{V}_{u}=$ urinary excretion; $\mathrm{V}_{f}=$ fecal endogenous excretion; $V_{o_{+}}=$deposition in bone; $V_{o_{-}}=$resorption from bone. From BRONNER and Aubert (1965).

(I) Supported in part by a grant from the United States Department of Agriculture under P. L. 480 . 
In order to estimate the various parameters of calcium metabolism a tracer level of calcium-45 is injected intravenously, and results of chemical and radio-assays are used in the mathematical solution of this model.

The solution of a similar model in the laying hen is difficult due to several factors : a) the existence of a slowly exchangeable calcium fraction in the plasma of this animal (HuRwiTz, I968), b) rapid bone turnover with possible return of calcium-45 from bone to circulation, $c$ ) the size of $\mathrm{E}_{1}$ which may change with the laying cycle, as reflected by the change in plasma calcium (HERTELENDY and TAYLOR, I96I) $d$ ) shell formation, which represents the greatest drain of calcium and is a discontinuous process.

The laying cycle in the hen is completed in about 25-30 hours, out of which egg shell is secreted during I9-20 hours. Since shell secretion occupies only part of the laying cycle, large metabolic changes must take place in the hen during the commencement and termination of this process. Such changes include the mobilization of large amounts of calcium and probably some respiratory changes needed in order to provide the large supply of $\mathrm{CO}_{2}$ to the forming shell.

Theoretically, this special need for calcium may be satisfied from the following sources : a) pool calcium, $b$ ) decrease in urinary calcium excretion $c$ ) excess of bone resorption over bone formation (net bone catabolism) and $d$ ) increase in calcium absorption.

\section{CHANGES IN POOL SIZE}

HERTELENDY and TAYLOR (3) reported a decrease in plasma calcium during shell formation with hens fed a 2 p. 100 calcium diet. Even if this observation holds under optimal calcium nutriture, the amount of calcium that may be gained from such change is in the range of a few milligrams compared to about 2 grams calcium needed for shell formation.

\section{DECREASE IN URINARY CAI,CIUM EXCRETION}

Several years ago we measured the rate of urinary excretion of calcium in colostomized birds (HURWITZ and GRIMINGER, I96I). The balance sheet of this experiment is given in table $\mathrm{I}$.

Urinary calcium excretion, although large relative to the size of the hen, amounts to only ro p. Ioo of the absorbed calcium. Any reduction in this excretion during shell formation can spare only a small fraction of the shell calcium. Such reduction has been recently reported by TAYLOR and KIRKLEY (I967), but it amounts to less per day than roo $\mathrm{mg}$. 
TABLE I

Calcium balance in colostomized bivds

\begin{tabular}{|c|c|}
\hline Parameter & $\begin{array}{l}\text { Amount } \\
\text { g/hen/day }\end{array}$ \\
\hline Intake & 3.00 \\
\hline Fecal excretion . . . . . . . . . . & 0.95 \\
\hline Urinary excretion $\ldots \ldots \ldots \ldots \ldots \ldots \ldots$ & 0.22 \\
\hline Deposition in egg $\ldots \ldots \ldots \ldots \ldots \ldots \ldots \ldots$ & 1.75 \\
\hline Apparent absorption $\ldots \ldots \ldots \ldots \ldots \ldots \ldots$ & 2.05 \\
\hline Retention $\ldots \ldots \ldots \ldots \ldots \ldots \ldots$ & 1.83 \\
\hline Balance $\ldots \ldots \ldots \ldots \ldots \ldots \ldots \ldots$ & 0.08 \\
\hline
\end{tabular}

\section{UTILIZATION OF BONE CAICIUM}

The importance of bone as a source of calcium for the egg shell, is well recognized. Bone calcium undergoes a contant turnover in which some of it is removed $\left(\mathrm{V}_{o}\right)$ and some is added to it $\left(\mathrm{V}_{o+}\right)$. The calcium leaving bone by the former process, enters and mixes in the pool, and can be secreted, as part of the pool-calcium, into the egg shell. When the hen is in calcium balance (steady state conditions), the bone neither looses nor gains any calcium. The calcium derived from bone is deposited in the egg shell without net calcium losses to the bone. Thus, this bone calcium which reaches the shell does not have any physiological significance.

On the other hand, when the animal is deprived of calcium, the skeleton can supply practically all the calcium needed for the egg shell. This process of net calcium removal from bone, which can continue until the animal is depleted up to about 30 p. IOO of its body calcium, is well documented (TAYLOR and MOORE, I956 ; HURWITZ and BAR, Ig66).

From calculations based on balance data, TAYLOR (I96I) attempted to show that during shell formation, the animal must draw upon its bone reserves. This calculation, using the data given in table $I$, is as follows : The average retention (from a 7 -day balance period) was $\mathrm{I} .83 \mathrm{~g} / 24$ hours or $76 \mathrm{mg} /$ hour. Since each shell contains $2.05 \mathrm{~g}$ calcium, and is secreted during about 20 hours, the rate of calcium deposition in the shell will be I02 $\mathrm{mg} /$ hour. It then follows that during periods of shell formation the hens are $26 \mathrm{mg} /$ hour short on their calcium supply, and that this extra calcium must come from the skeleton. The calcium lost from the skeleton during shell formation will be repleted when no shell is formed, and at the end of the cycle, the hen will be in calcium balance.

This calculation is based on the assumption that the rate of calcium absorption does not change during the laying cycle. It will be shown below that this assumption is not valid.

Furthermore, if this calculation is correct, it must be possible to detect quantitative changes in bone calcium during the laying cycle. In a study in which we investigated the kinetic behaviour of calcium-45 in the laying hen (HuRwiTz, I964), we 
also obtained some data on bone composition. In this experiment, we were unable to show any changes in the calcium content of medullary as well as structural bone, during the laying cycle. It should be emphasized that the birds used in this study were fed during their laying period diets containing 3.5-4.0 p. Ioo calcium.

The above findings raised the questions of the entire validity of TAYLOR's calculation. As no net changes in bone calcium could be detected, and since the skeleton is the only large enough reservoir of calcium in the body, an increase in intestinal absorption of calcium remained the only means by which the animal could obtain the amount of calcium it needed.

\section{VARIATIONS IN INTESTINAI, CALCIUM ABSORPTION}

The classical balance technique has been widely used to study the calcium retention in the laying hen. Some studies were conducted with colostomized animals in order to measure the apparent calcium absorption which is about to p. roo larger than retention.

Due to the delay of about 6 hours between ingestion and excretion it is impossible to use balance techniques for studies of short duration. Such techniques are suitable for long term experiments in which the differences between the intakes at the beginning and end of the balance trial become insignifiant. Therefore, the balance method could not be used to study the variations in calcium absorption during the laying cycle. The use of an unabsorbed reference substance, for this purpose, seemed most appropriate. Our study involved yttrium-gr as the reference substance (HuRWITZ and BAR, I965).

Two groups of hens were fed diets containing, respectively, I.90 and $3.56 \mathrm{p}$. Ioo calcium. Both diets were uniformly labelled with yttrium-gr. After four days on the respective diets, the hens were killed and their intestine separated into various segments, the contents of which were analyzed for calcium and yttrium-9I. The apparent absorption at any level of the intestine were calculated from $\mathrm{Ca} / \mathrm{Y}-\mathrm{g}$ I ratio.

From each group of hens, some were killed during early shell calcification, some during late shell calcification and others, when no shell was formed.

The overall absorption calculated from the $\mathrm{Ca} / \mathrm{Y}-\mathrm{gI}$ ratio at the distal intestine, is given in table 2 .

4 TABIE 2

The percentage of net calcium absorption in laying hens, as infuenced by shell formation and dietary calcium

\begin{tabular}{|c|c|c|}
\hline \multirow{2}{*}{ Shell calcification } & \multicolumn{2}{|c|}{ Dietary Ca, \% } \\
\hline & 3.56 & 1.90 \\
\hline & \multicolumn{2}{|c|}{$\%$ absorption } \\
\hline None $\ldots \ldots \ldots \ldots \ldots \ldots \ldots \ldots$ & 40.0 & 40.1 \\
\hline Early $\ldots \ldots \ldots \ldots \ldots \ldots \ldots$ & 68.3 & 77.3 \\
\hline Late $\ldots \ldots \ldots \ldots \ldots \ldots \ldots$ & 72.4 & 71.1 \\
\hline
\end{tabular}


Although percentage absorption was somewhat higher for hens receiving the lower calcium diet, this difference was not significant, the changes in calcium absorption, due to shell formation are rather striking, with absorption almost doubled. There was little difference between periods of early and late calcification. More recent work of TAYLOR and associates (I967) also found the absorption of calcium greater in laying days as compared to non laying days.

The percentage absorption of $70-80 \mathrm{p}$. Ioo may be considered maximal, since even at much lower levels of dietary calcium it would rearely exceed this limit.

If one assumes a constant supply of nutrients into the digestive tract (according to our experience this situation is approached), one can calculate the rate of calcium absorption during shell formation. This rate is 104 and $58 \mathrm{mg}$ per hour, for the 3.56 p. roo and the r.90 p. Ioo calcium diets, respectively. For the hens receiving the high calcium diet the calcium absorbed is sufficient to meet the need, if the rate of shell calcification is constant, but this is not the case with those receiving the low calcium diet.

This experiment explicitely shows that when the calcium intake is sufficient, and continues during periods of shell formation, there is little need for bone to contribute any net amount of calcium to the egg shell. The intestine has proved to be of utmost importance in the calcium homeostasis of the laying hen.

It is evident that the moderately low calcium diet of I.90 p. Ioo was insufficient to enhance absorption above what we termed above the maximum percentage absorption. Undoubtedly, the birds receiving this diet had been in negative calcium balance, and would have returned to balance by reduction in shell secretion and rate of egg production (HURWI'TZ and GRIMINGER, Ig6o). It was, therefore, of importance to see whether the intestine reacts more rapidly to a challenge of an acute calcium deficiency.

\section{EFFECT OF ACUTE DEPLETION ON CALCIUM ABSORPTION}

The classical balance method was sufficient for studying this problem since we did not look for hour to hour changes in absorption (HURWITZ and BAR, I966).

Two groups of hens were fed for 6 days (control period) diets containing r.82 and 3.92 p. Ioo calcium, respectively. This control period was followed by a 2 -day depletion period during which all birds received a "calcium-free " $\operatorname{diet}$ (0.I 2 p. Ioo calcium). Lastly, the hens were returned to their original diets for additional 6 days (repletion period). Calcium balances were conducted during the control and repletion periods.

Results of this experiment (table 3 ) indicate that hens of both groups responded to the challenge of calcium depletion by a substantial increase in their calcium absorption.

The combination of an increase in absorption with the decrease in shell secretion, enabled the birds to maintain a positive calcium balance during repletion, thus repleting their skeleton. In the I.82 p. Ioo calcium-birds, the absorption of calcium had not immediately reached the maximal value, although they were in a distinct negative balance. This would suggest that the response of the intestine to the challenge of calcium depletion is to some degree proportional to the magnitude of the challenge. 
TABI,E 3

Effect of a 2-day calcium depletion on calcium balance of laying hens

\begin{tabular}{|c|c|c|c|c|}
\hline \multirow{2}{*}{$\frac{\text { Dietary Ca, \% }}{\text { Period }}$} & \multicolumn{2}{|c|}{1.82} & \multicolumn{2}{|c|}{3.93} \\
\hline & Control & Repletion & Control & Repletion \\
\hline Ca intake, g/day .. & 2.06 & $2.0 \pm$ & 4.13 & 4.00 \\
\hline Ca excretion, g/day & 0.70 & 0.52 & 2.34 & 1.96 \\
\hline Ca retention, g/day & 1.36 & 1.51 & 1.79 & $2.0_{4}^{\prime}$ \\
\hline Egg Ca, g/day .... & 1.56 & 1.38 & 1.77 & 1.43 \\
\hline Ca balance, g/day. & -0.20 & 0.13 & 0.02 & 0.61 \\
\hline Ca retention, $\% \ldots$ & 66.2 & 74.6 & 43.1 & 51.3 \\
\hline
\end{tabular}

\section{THE MECHANISM OF REGULATION OF CALCIUM ABSORPTION}

We have demonstrated the role of the intestine in calcium homeostasis in two instances : a response to a stimulus of an increase in the calcium need due to shell formation, and a response to a challenge of calcium deprivation. We have, however no indication if the mechanism of this response is the same or different in those two instances.

KIMBERG et al. (I96I) showed that " active transport " of calcium developed in intestinal segments lower than the duodenum in rats subject to a low calcium regime. 'This conclusion was based on in vitro studies. Meddaiah and Bronner (I968) showed that the appearance of calcium binding protein ( $\mathrm{CaBP}$ ) in the intestinal mucosa was an inverse function of dietary calcitum, and associated its appearance with the action of the parathyroids. It is most tempting to extrapolate these findings to the regulation of calcium absorption by the laying hen-intestine. However, before doing so one must evaluate the mechanism of calcium absorption in the hen : is it uphill or downhill, and if the latter, is it simple or facilitated diffusion.

After developing an in vitro system for laying hen intestine, Mr. BAR, in our laboratory, investigated the mechanism of the mucosal transport of calcium (BAR and HuRwitz, I969). On the basis of kinetic evidence and the use of certain inhibitors, it was concluded that the mucosal uptake of calcium was a simple diffusion process. The mucosal uptake can be considered the first step in absorption, and therefore a mechanism other than simple diffusion may still exist for the subsequent transport of calcium. In an effort to study the transmural transport of calcium in the laying hen intestine, we tried gut loops, a preparation similar to that used with rat intestine (KIMBERT et al., I96I). Unfortunately, the laying hen intestine was found to be impermeable to calcium, under in vitro conditions.

The other more difficult possibility was to study the calcium transport in vivo and relate it to the corresponding driving forces operating on intestinal calcium.

The first study of this type has been recently reported (Hurwitz and BAR, I968). This study involved measurements of luminal calcium activity, and trans- 
mural electrical potential, as well as estimation of the net calcium absorption, using yttrium-gr. The results of this study, as well as other experiments, tend to suggest simple diffusion as the mechanism of calcium absorption, in vivo, in the laying hen. However, considerable more evidence is needed to support this conclusion.

As mentioned above, regulation of calcium absorption can be explained readily if active transport and a calcium carrier are evoked. But if calcium is transported by simple diffusion, how could it be physiologically controlled? HARRISON and HARRISON (1965) clearly showed mucosa to be a permeability barrier for calcium. SchachTer (I963) showed that this permeability barrier in the rat jejunum and ileum was oxygendependent. It thus seems possible that by some metabolic change, the permeability of the mucosa for calcium can be modified, thus effecting the regulation of intestinal absorption.

\section{SUMMARY}

In the laying hen, calcium intestinal absorption increases during egg shell formation. On account of this increase, skeleton calcium input in egg shell is poor.

Calcium absorption also increases when the animal is fed a diet poor in calcium.

We may conclude that in the laying hen, intestine plays an important part in calcic homeostasis. The possible cause of this regulation is discussed.

\section{RÉSUMÉ}

\section{RÔLE DE L'INTESTIN DANS " L'HOMÉOSTASIE CALCIQUE » DE LA POULE PONDEUSE}

L'absorption intestinale du calcium augmente chez la poule pondeuse pendant la formation de la coquille de l'œuf. Du fait de cette augmentation, la contribution en calcium du squelette pour la coquille de l'œuf est faible.

L'absorption du calcium augmente également lorsque l'animal reçoit un régime carencé en calcium.

Il en est conclu que l'intestin joue un rôle important dans l'homéostasie calcique de la poule pondeuse. La cause possible de cette régulation est discutée.

\section{REFERENCES}

Bar A., Hurwitz S., 1969. In vityo calcium transport in laying fowl intestine : characterization of the system and medium composition. Poultry Sci., 48, I Io5-III3.

BAR A., HURwitz S., I969. The accumulation of calcium in laying fowl intestine in vitro. Biochim. Biophys. Acta, 183, 59I-60o.

Bronner F., Auber'T J.-P., I965. Bone metabolism and regulation of the blood calcium level in rats. Amer. J. Physiol., 209, 887-890.

Harrison H. E., Harrison H. C., I965. Vitamin D and permeability of intestinal mucosa to calcium. Amer. J. Physiol., 208, 370-374.

Hertelendy F., TAYlor T. G., I96r. Changes in blood calcium associated with egg shell calcification in the domestic fowl. I. Changes in the total calcium. Poultry Sci., 40, ro8-I 4 .

Hurwitz S., 1964. Bone composition and $\mathrm{Ca}^{45}$ retention in fowl as influenced by egg formation. Amer. J. Physiol, 206, 198-204. 
Hurwitz S., 1968. Calcium exchange in plasma of the fowl, Biochim. Biophys. Acta, 156, $389-393$.

Hurwitz S., BAR A., r 965 . Absorption of calcium and phosphorus along the gastrointestinal tract of the laying fowl as influenced by dietary calcium and egg shell formation. J. Nutrition, 86, 433-438.

Hurwitz S., BAR A., I966. Calcium depletion and repletion in laying hens. I. Effect on calcium in various bone segments, in egg shell and in blood plasma, and on calcium balance. Poultry Sci., 45, $345-352$.

Hurwitz S., Bar A., sg68. Activity, concentration and lumen-blood electrochemical potential difference of calcium in the intestine of the laying hen. $J$. Nutrition, 95, 647 .

Hurwitz S., Griminger P., I960. Observations on the calcium balance of layring hens. J. Agric., $54,373-377$

Hurwitz S., Griminger P., I96I. Partition of calcium and phosphorus excretion in the laying hen. Nature, 189, 759-760.

Kimberg D. V., Schachter D., Schenker H., I96r. Active transport of calcium by intestine : effect of dietary calcium. Amer. J. Physiol., 200, I256-1262.

Meddaiah V. T., Bronner Ti, I968. Calcium transport and calcium binding protein (CaBP) of rats. Symposium on Biophysical Aspects of Permeability, Jerusalem, p. 18.

SCHACHTER D., I963. Vitamin $D$ and the active transport of calcium by the small intestine. In : WASSERMAN, R. H., The Transfer of Calcium and Strontium across Biological Membranes, Academic Press, New York, p. 197-2 Io.

TAYLOR T. G., I96r. Calcium absorption and metabolism in the laying hen. In : MORGAN J. T. and LEWIS D. Nutrition of Pigs and Poultry, Butterworths, London, p. I48-I57.

TAYLOR T. G., KIRKLEY J., I967. The absorption and excretion of minerals by laying hens in relation to egg shell formation. Brit. Poultry Sci., 8, 289-295.

TAYLOR T. G., MOORE J. H., I956. The effect of calcium depletion on the chemical composition of bone minerals in laying hens. Brit. J. Nutrition, 10, 250. 